\title{
Incidental Carcinoma Gallbladder: Presenting As Metastatic Satellite Nodules in Anterior Abdominal Wall - A Rare Case Report
}

\author{
Wasif Mohd Ali*, Zaid Imbisat, Syed Amjad Ali Rizvi and Atia Zaka-ur-Rab \\ Department of surgery, Jawaharlal Nehru Medical College, India
}

Submission: February 02, 2017; Published: February 27, 2017

"Corresponding author: Wasif Mohd Ali, Department of surgery, Jawaharlal Nehru Medical College, India, Tel: 9897238280;

Email: aliwasif110@gmail.com

\begin{abstract}
Carcinoma gallbladder is well known for its aggressive behaviour and usually metastasize through lymphatics, hematogenous route and direct spread to the peritoneal cavity along the port sites. Distant metastasis in the subcutaneous space presenting as satellite nodules in the anterior abdominal wall away from the port sites is an extremely rare presentation and we are reporting a similar case in incidentally diagnosed carcinoma gallbladder. A 50 yrs female patient underwent laparoscopic cholecystectomy for symptomatic cholelithiasis but histopathology of her gallbladder was suggestive of adenomatous polyp. Her immediate post operative recovery was satisfactory but patient again presented with multiple subcutaneous nodules in anterior abdominal wall which came out to be adenocarcinoma on histopathology. Her USG Abdomen was suggestive of seedling metastasis and CECT Abdomen was suggestive of hypoechoic lesions in segment 4, 5 and 6 of liver. So patient was diagnosed as a case of incidentally diagnosed case of carcinoma gallbladder presenting with metastatic satellite nodules in subcutaneous space of anterior abdominal wall.
\end{abstract}

\section{Introduction}

Biliary tract diseases are commonly encountered in our daily practices and range from benign to malignant diseases. Gall bladder cancer is the sixth most common malignancy of gastrointestinal tract and most common malignancy of biliary tract [1]. It is well known for its aggressive behavior and poor prognosis. However, the patient having carcinoma gallbladder may present with right upper abdominal pain, nausea, vomiting and features of cholangitis but owing to its nonspecific symptoms gallbladder carcinoma is generally diagnosed late in the disease course [2]. Carcinoma gallbladder has the property to metastasize through lymphatics, hematogenous route and direct spread to the peritoneal cavity along the port sites $[3,4]$. But metastasis to distant subcutaneous site is extremely rare [5]. We report a rare case of metastasis in the anterior abdominal wall in the form of satellite lesion from the carcinoma gall bladder after taking the proper informed consent from the patient.

Case

Patient named Guddi 50 years female presented to surgery OPD in November 2014 with complain of pain in right upper abdomen on and off. On examination abdomen was soft, non tender, and no lump was palpable. Her USG abdomen was suggestive of cholelithiasis and patient was planned for laparoscopic cholecystectomy which was done in December 2014. Her immediate post operative period was uneventful and patient was discharged in satisfactory condition to be followed up in OPD. Her histopathology report of gallbladder was suggestive of adenomatous polyp.

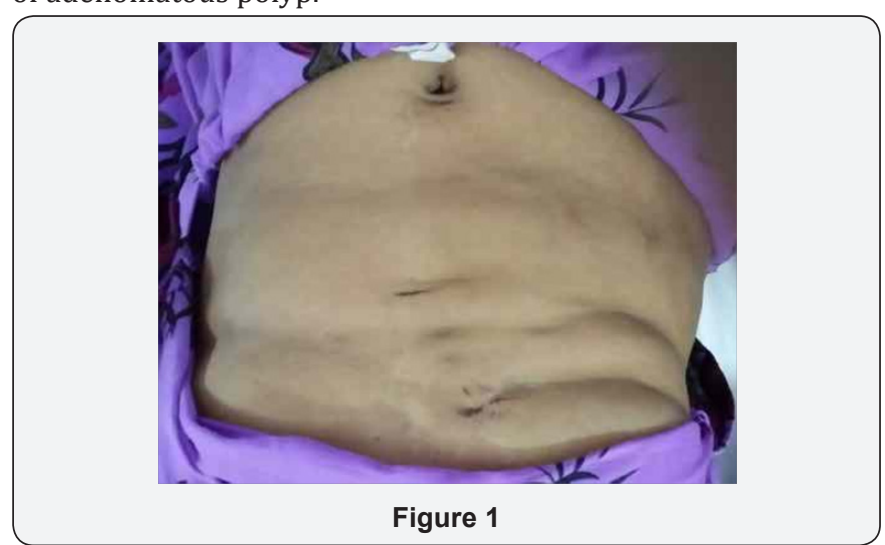


Patient again presented in OPD after six months of surgery with complain of pain right upper abdomen. On examination multiple palpable subcutaneous nodules were present in the upper abdominal wall distant from the port sites (Figure1). Her USG abdomen was suggestive of small hypoechoic lesion of $10 \mathrm{~mm}$ diameter in segment 4 and 5 of liver with parietal wall thickening seen in right upper abdomen suggesting seedling metastasis. Her CECT whole abdomen was suggestive of heterogeneously enhancing soft tissue density lesions within the subcutaneous plane of anterior abdominal wall aborting the right rectus abdominis muscle with indistinct fat plane which appear heterogeneous; and bulky and ill defined heterogeneously enhancing hypodense lesion in segment 4, 5 and 6 of liver (Figure2). Histopathological examination of subcutaneous nodule was suggestive of adenocarcinoma (Figure3). Therefore the patient was diagnosed as case of incidentally diagnosed carcinoma gallbladder presenting with distant metastasis as satellite nodules in the anterior abdominal wall and post operative chemotherapy is planned.
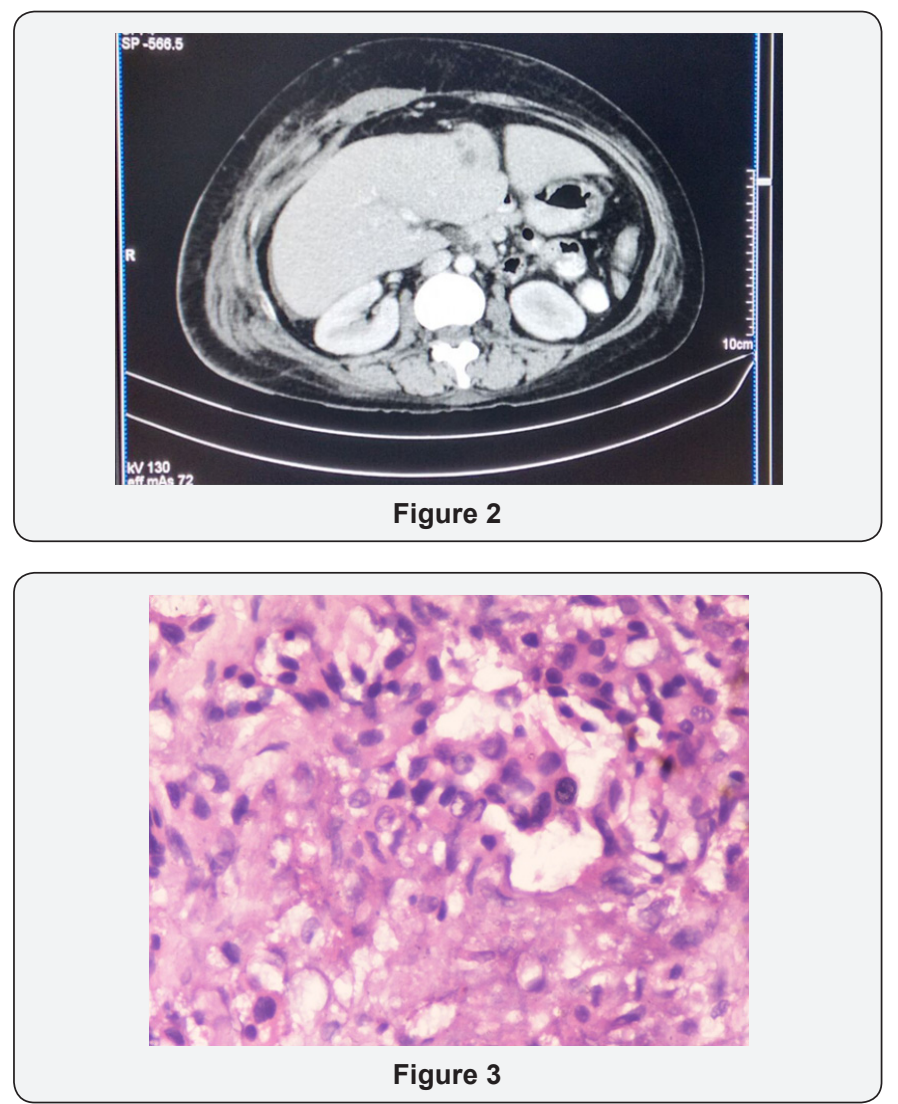

\section{Discussion}

Gallbladder cancer is the most common malignancy of biliary tract and sixth most common malignancy of gastrointestinal tract. Incidence increases with age [6] and is more common among females (incidence rate ratio 1.24-2.86) [7]. It is well known for its aggressive behaviour and poor prognosis and 5 year survival rate is 0.5 to 12 percent and median survival of 2 to 19 months depending on the stage of disease [2,8]. However the most characterized risk factor for the development of carcinoma gallbladder is chronic inflammation associated with gall stones other factors like porcelain gallbladder, adenomatous polyp, S.typhi infection, carcinogen exposure, ABPDJ are also found to be risk factors for carcinoma gallbladder [9]. Most of the patients remain asymptomatic in the absence of advance disease and in various studies incidence of incidentally diagnosed cases of carcinoma gallbladder is up to 2.85 percent. Carcinoma gallbladder is well known for its metastasis along the lymphatics, through hematogenous route, direct spread to peritoneal cavity and along the port sites. Metastasis to the subcutaneous space, presenting as satellite nodules in the anterior abdominal wall is very rare presentation of carcinoma gallbladder and should be kept in mind.

\section{Conclusion}

Carcinoma gallbladder may present as metastatic satellite nodules in subcutaneous space of anterior abdominal wall, however it is an extremely rare presentation.

\section{References}

1. Russo MW, Wei JT, Thiny MT, Gangarosa LM, Brown A, et al. (2004) Digestive and liver diseases statistics 2004. Gastroenterology 126(5): 1448-1453.

2. Misra S, Chaturbedi A, Misra NC, Sharma ID (2003) Carcinoma of gallbladder. Lancet oncol 4(3): 167-176.

3. Garg PK, Khurana N, Hadke NS (2009) Subcutaneous and breast metastasis from asymptomatic gallbladder carcinoma. Hepatobiliary Pancreatic Dis Int 8(2): 209-211

4. Kondo S, Nimura Y, Kamiya J, Nagino M, Kanai M, et al. (2002) Mode of tumour spread and surgical strategy in gall bladder carcinoma. Langenbacks Arch surg 387(5-6): 222-228.

5. Sean F Heavy, Eric J Roeland, Ann M, Ponsford (2014) Rapidly progressive subcutaneous metastasis from gallbladder cancer: Insight into a rare presentation in gastrointestinal malignancies. J Gastrointest Oncol 5(4): E58-64.

6. Lazcano-Ponce EC, Miquel JF, Muñoz N, Herrero R, Ferrecio C, et al. (2011) Epidemiology and molecular pathology of gallbladder cancer. CA cancer J Clin 51(6): 349-364.

7. Castro FA, Koshiol J, Hsing AW (2013) Bilairy tract cancer incidence in the united state-Demographic and temporal variation by anatomic site. Int J Cancer 133(7): 1644-1671.

8. Wistuba II, Gazdar AF (2004) Gallbladder cancer: lessons from a rare tumour. Nat Rev Cancer 4(9): 695-706.

9. Ciombor KK, Goff LN (2013) Current therapy and future directions in biliary tract malignancies. Curr treat options oncol 14(3): 337-349. 


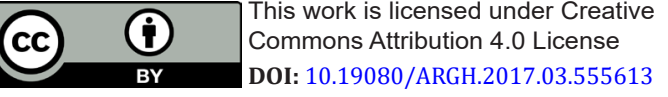

- Quality Editorial service

- Swift Peer Review

- Reprints availability

- E-prints Service

- Manuscript Podcast for convenient understanding

- Global attainment for your research

- Manuscript accessibility in different formats

( Pdf, E-pub, Full Text, Audio)

- Unceasing customer service

Track the below URL for one-step submission https://juniperpublishers.com/online-submission.php 